\title{
PENGEMBANGAN MEDIA PEMBELAJARAN VIDEO TUTORIAL MENGGUNAKAN CAMTASIA STUDIO 8.5 PADA MATAKULIAH SISTEM INFORMASI GEOGRAFI (SIG)
}

\author{
Riki Rahmad ${ }^{1}$, Eni Yuniastuti ${ }^{2}$, Mona Adria Wirda ${ }^{3}$ \\ Jurusan Pendidikan Geografi Fakultas Ilmu Sosial Universitas Negeri Medan \\ Email: rikirahmad@unimed.ac.id
}

\begin{abstract}
ABSTRAK
Penelitian ini bertujuan untuk menghasilkan media pembelajaran dalam bentuk video tutorial menggunakan aplikasi Camtasia Studio 8.5 pada mata kuliah Sistem Informasi Geografi (SIG) di Jurusan Pendidikan Geografi Fakultas Ilmu Sosial Universitas Negeri Medan. Langkah-langkah dalam penelitian pengembangan ini adalah: (1)tahap pendahuluan, (2) tahap perancangan media video tutorial, (3) tahap pembuatan media video tutorial, (4) tahap validasi media, (5) tahap pengujian media video tutorial, dan (6)tahap evaluasi media. Hasil penelitian menunjukkan Hasil uji kelayakan dari segi materi pada pengembangan video tutorial menggunakan Camtasia Studio 8.5 pada matakuliah Sistem Informasi Geografi (SIG) dikategorikan sangat layak untuk digunakan dengan catatan perlu dilakukan revisi. Sedangkan hasil uji kelayakan dari segi media dikategorikan cukup layak digunakan dengan beberapa revisi, diantaranya: penambahan teks dan tulisan, musik, detail petunjuk tombol, dan lain sebagainya. Hasil respon mahasiswa mengenai pengembangan video tutorial menggunakan Camtasia Studio 8.5 pada matakuliah Sistem Informasi Geografi (SIG) masuk dalam kategori baik. Hal ini menunjukkan bahwa pengembangan video sudah bagus dan mendapatkan respon positif dari mahasiswa.
\end{abstract}

Kata Kunci: pembelajaran, media, Camtasia Studio, SIG

\begin{abstract}
This study aims to produce instructional media in the form of video tutorial using Camtasia Studio 8.5 application in Geography Information System (GIS) course in Geography Education Department Faculty of Social Sciences, Universitas Negeri Medan. The steps in this development research are: (1) preliminary stage, (2) video tutorial design stage, (3) video media tutorial development stage, (4) media validation stage, (5) video media tutorial testing stage, and (6) stage of media evaluation. The results showed that the results of the material feasibility test on the development of video tutorials using Camtasia Studio 8.5 in the Geography Information System (GIS) course are considered very appropriate to be used with the need to revise. While the feasibility test results in terms of media categorized quite feasible to use with some revisions, including: the addition of text and writing, music, detail buttons, and so forth. The result of student's response about video tutorial development using Camtasia Studio 8.5 on Geography Information System (GIS) course in good category. This shows that video development is good and get positive response from students.
\end{abstract}

Keywords: learning, media, Camtasia Studio, GIS).

\section{PENDAHULUAN}

Sistem pendidikan saat ini sedang mengalami perubahan yang cukup pesat. Perubahan tersebut mempunyai tujuan untuk memperbaiki sistem pendidikan yang telah ada sebelumnya.Berbagai pendekatan baru telah diperkenalkan dan digunakan agar proses belajar menjadi lebih berkesan dan bermakna. Teknologi merupakan salah satu 
faktor yang paling dominan dalam perubahan sistem pendidikan. Dengan adanya teknologi maka pembelajaran akan semakin efektif dan efisien (Pritandhari \& Ratnawuri, 2015).

Di era globalisasi kemajuan teknologi dan perkembangan ilmu pengetahuan semakin pesat dari waktu kewaktu, sehingga dalam dunia pendidikan pun ikut bersaing dalam kemajuan teknologi. Tidak bisa dipungkiri bahwa teknologi multimedia mampu memberi dampak besar dalam komunikasi dan pendidikan karena bisa mengintegrasikan teks, grafik, animasi, audio dan video serta mengembangkan proses belajar ke arah yang lebih dinamis.

Pemanfaatan teknologi multimedia tidak lagi sesuatu hal yang sulit karena lamakelamaan pada saat sekarang ini sudah mulai bisa dijangkau oleh segenap lapisan masyarakat. Artinya, kampus yang merupakan lembaga pendidikan harus bisa mengikuti dan menunjang perkembangan teknologi agar dapat dijadikan sebagai media pembelajaran yang lebih menarik, interaktif, bervariasi dan mampu mengembangkan pengetahuan mahasiswa serta memperluas wawasan terhadap materi-materi yang diajarkan (Aulia \& Aina, 2016).

Pembelajaran akan lebih menarik jika ada kombinasi yang tepat antara pemilihan metode pembelajaran dengan media yang digunakan. Metode pembelajaran yang baik dipilih oleh dosen sebaiknya harus disesuaikan dengan materi sehingga menimbulkan kesan yang positif dalam diri mahasiswa. Dengan adanya kesan positif maka materi yang telah disampaikan akan mudah dipahami dan tidak hilang begitu saja seiring dengan datangnya materi-materi baru ataupun karena faktor lain.

Sistem Informasi Geografi (SIG) sebagai salah satu mata kuliah sistem komputer yang digunakan untuk akuisi (perolehan) dan verifikasi, kompilasi, penyimpanan,perubahan (updating) manajemen dan pertukaran, manipulasi, pemanggilan danpresentasi, serta analisis geografi. Mata kuliah SIG perlu direvitalisasi denganmemfungsikannya sebagai mata kuliah pengembangan kepribadian yang difokuskanpada keterampilan mengoperasikan berbagai software SIG. Terkait dengan permasalahan ini,mahasiswa harus dilibatkan dalam berbagai kegiatan yang membantu mereka untukmencapai pemahaman yang mantap tentang aplikasi program SIG.

Ada berbagai strategi pembelajaran yang berbeda dapat digunakan di dalam proses belajar mengajar sehingga memungkinkan mahasiswa memperoleh pengalaman belajar yang berbeda. Dengan demikian masalahnya adalah apakah strategi pembelajaran yang berbeda memberikan pengaruh yang berbeda terhadap prestasi belajar mahasiswa. Berbagai upaya yang dilakukan dosen untuk meningkatkan prestasi belajar mahasiswa khususnya pada mata kuliah Sistem Informasi Geografi (SIG).

Materi praktik SIG selama ini dijelaskan menggunakan infokus LCD oleh dosen kepada mahasiswa. Pada saat dijelaskan aplikasi di kelas mahasiswa cukup paham, namun daya ingat terbatas untuk memahaminya pada pertemuan berikutnya. Untuk mengingat kembali materi yang sudah disampaikan mahasiswa membuka hasil catatannya. Namun hasil catatan mereka belum maksimal. Dosen terkadang harus mengulang kembali materi pada pertemuan sebelumnya.

Mahasiswa secara visual dapat memahami aplikasi SIG melalui panduan praktikum. Namun, berdasarkan keterangan mahasiswa yang sudah pernah mengambil mata kuliah SIG panduan praktikum yang ada sulit untuk dipahami. Hal ini disebabkan ada langkah-langkah yang tidak tertulis dan sistematika penyajian tidak berurutan sesuai yang dipraktikumkan. Berdasarkan analisis kebutuhan maka pembelajaran SIG dibutuhkan media yang mampu memberikan pemahaman lebih kepada mahasiswa. Maka dari itu fokus masalah dalam penelitian ini berkaitan dengan multimedia tutorial yang dapat digunakan dimana saja dan kapan saja, sehingga harapannya dapat meningkatkan pemahaman mahasiswa terhadap teori dan aplikasi SIG khususnya pada sofware ArcGIS.

Masalah-masalah yang timbul sehubungan dengan pembelajaran SIG 
antara lain: 1) seringkali dosen mendapat kenyataan yang berbeda, misalnya setelah menyampaikan materi dalam bentuk ceramah cukup lama, namun setelah ditanya sebagian besar mahasiswa tidak mengerti apa yang telah disampaikan; 2) mata kuliah SIG perlu direvitalisasi dengan memfungsikannya sebagai mata kuliah pengembangan kepribadian yang difokuskan pada keterampilan mengoperasikan komputer; 3) nilai mata kuliah SIG belum maksimal sehingga dibutuhkan perbaikan metode maupun strategi dalam pembelajaran SIG; 4) dosen perlu menggunakan media pembelajaran yang inovatif; 5) mahasiswa membutuhkan media pembelajaran lain yang lebih tutorial dan mudah dipahami dibanding dengan media pembelajaran yang sudah ada; 6) dosen perlu menyediakan bahan belajar yang bisa diakses sewaktu-waktu di luar jam kuliah; 7) pembelajaran SIG dibutuhkan multimedia tutorial yang mampu memberikan pemahaman lebih kepada mahasiswa berupa keterampilan mengoperasikan software SIG.

Penelitian ini dilaksanakan dengan tujuan menghasilkan media pembelajaran dalam bentuk video tutorial menggunakan aplikasi Camtasia Studio 8.5 pada matakuliah Sistem Informasi Geografi (SIG).

\section{METODE PENELITIAN}

Pendekatan penelitian yang dilaksanakan yaitu pendekatan penelitian dan pengembangan Pendidikan (Education Research and Development). Penelitian dan pengembangan pendidikan adalah suatu strategi untuk mengembangkan produk pendidikan yang efektif. Penelitian dan pengembangan pendidikan merupakan suatu industri berbasiskan pengembangan model dimana penemuan-penemuan penelitian digunakan untuk mengembangkan produk yang baru dan prosedur yang baru, yang kemudian secara sistematik dilakukan uji lapangan, evaluasi, dan revisi sampai diperoleh/dicapai kriteria efektivitas dan kualitas tertentu atau mencapai standar tertentu (Gall, Gall and Borg, 2003). Maksud dari penelitian pengembangan adalah menjembatani jurang pemisah yang sering ditemui antara penelitian pendidikan dengan praktik pendidikan sehari-hari (Gall and Borg, 1979).

Penelitian ini merupakan penelitian dan pengembangan model pembelajaran, khususnya produk pembelajaran berupa multimedia tutorial untuk mata kuliah SIG menggunakan aplikasi Camtasia Studio 8.5. Multimedia tutorial ini dimaksud sebagai media yang terintegrasi dalam proses pembelajaran, walaupun sifatnya tutorial, tetapi bahan belajar ini tidak bermaksud menggantikan peran dosen dalam proses pembelajaran, walaupun memang dimungkinkan untuk itu. Oleh karena itu, kerangka penelitian secara garis besar ditata dengan urutan sebagai berikut: mengumpulkan data kondisi saat ini untuk analisis kebutuhan; analisis data; mengembangkan dan memilih alternatif tindakan.

Penelitian dilaksanakan di Laboratorium Sistem Informasi Geografi (SIG) Jurusan Pendidikan Geografi Fakultas Ilmu Sosial Universitas Negeri Medan. Adapun waktu penelitian ini direncanakan berlangsung selama 6(enam) bulan dari bulan Mei 2017 sampai dengan November 2017.

Populasi dalam penelitian ini ialah seluruh mahasiswa pada matakuliah Sistem Informasi Geografi (SIG) di Jurusan Pendidikan Geografi Tahun Ajaran 2017/2018. Sampel penelitian diambil secara acak, dipilih satu kelas yang kemampuan mahasiswa cenderung seragam, baik kemampuan kognitif maupun psikomotorik. Berdasarkan kriteria ini maka dipilih kelas A reguler TA 2017/2018 sebagai sampel penelitian.

Penelitian ini akan dilaksanakan selama 6 bulan dari bulan Mei-Oktober 2017. Tahap awal penelitian berupa pengembangan video tutorial yang mengacu pada model Thiagarajan dan Semmel \&Semmel yang terdiri dari empat tahap yaitu: tahap define (penetapan), design (perancangan), develop (pengembangan), dan dessiminate (penyebaran). Tahap define dan design masuk pada fase perencanaan pengembangan sedangkan 
develop dan dessiminate masuk dalam fase pengembangan.

Tahap perencanaan produk dilakukan melalui dua tahap perancangan, yaitu perancangan story board dan perancangan interface atau desain tampilan pada komputer. Karena video tutorial yang dikembangkan akan ditampilkan dalam komputer sebagai antar muka antara media dengan pengguna, maka perancangan tampilan pada komputer penting dilakukan untuk membuat media lebih interaktif di kalangan user atau pengguna.

Pembuatan produk dilakukan berdasarkan perancangan media yangtelah disusun sebelumnya. Setiap langkah pembuatan akan memaparkan komponen rancangan produk yang dikembangkan. Prosedur pengembangan secara tidak langsung memberikan petunjuk mengenai langkah prosedural dalam menghasilkan spesifikasi produk yang memenuhi kriteria tertentu sesuai tujuan.
Video tutorial yang sudah dikembangkan kemudian akan divalidasi oleh 2 orang validator internal sebanyak dua kali untuk mengukur kelayakan video tutorial. Hasil validasi pertama akan menjadi bahan acuan untuk merevisi kembali video tutorial. Video tutorial yang sudah direvisi tersebut divalidasi kembali oleh validator yang sama sampai akhirnya dihasilkan video yang sudah layak untuk digunakan dalam perkuliahan. Tahap kedua, berupa penggunaan video tutorial sebagai media yang dikembangkan pada matakuliah Sistem Informasi Geografi di lokal ARegular TA 2016/2017. Tahap Ketiga, menganalisis respon mahasiswa pengguna video tutorial tersebut.

Data yang dikumpulkan dan teknik pengumpulan datanya sebagai berikut:

Pertama, data kelayakan video tutorial diperoleh melalui penilaian 2 orang validator yang terdiri dari validator materi dan validator media. instrumen validasi dapat dilihat pada Tabel 1.

Tabel 1. Instrumen Validasi Materi

\begin{tabular}{|c|c|c|c|c|c|}
\hline \multirow{2}{*}{ No } & \multirow{2}{*}{ Pernyataan } & \multicolumn{4}{|c|}{ Skor Penilaian } \\
\hline & & 1 & 2 & 3 & 4 \\
\hline & ASPEK KUALITAS MATERI & & & & \\
\hline & I. Ketepatan isi dengan kompetensi yang ingin dicapai & & & & \\
\hline 1 & $\begin{array}{l}\text { Ketepatan isi materi Menampilkan Peta Hasil Scan dengan kompetensi } \\
\text { yang ingin dicapai }\end{array}$ & & & & \\
\hline 2 & $\begin{array}{l}\text { Ketepatan isi materi Koreksi/Registrasi Peta Hasil Scan dengan } \\
\text { kompetensi vang ingin dicapai }\end{array}$ & & & & \\
\hline 3 & $\begin{array}{l}\text { Ketepatan isi materi Digitasi Elemen Titik, Garis, dan Luasan dengan } \\
\text { kompetensi yang ingin dicapai }\end{array}$ & & & & \\
\hline 4 & $\begin{array}{l}\text { Ketepatan isi materi Entry attribut Elemen Titik, Garis, dan Luasan } \\
\text { dengan kompetensi yang ingin dicapai }\end{array}$ & & & & \\
\hline 5 & $\begin{array}{l}\text { Ketepatan isi materi Analisis Data Atribut dan Pengukuran dengan } \\
\text { kompetensi yang ingin dicapai }\end{array}$ & & & & \\
\hline 6 & $\begin{array}{l}\text { Ketepatan isi materi Layouting/Tata Letak Peta dengan kompetensi yang } \\
\text { ingin dicapai }\end{array}$ & & & & \\
\hline & II. Kelengkapan Materi & & & & \\
\hline 7 & $\begin{array}{l}\text { Kelengkapan Materi Menampilkan Peta Hasil Scan dengan kompetensi } \\
\text { yang ingin dicapai }\end{array}$ & & & & \\
\hline 8 & $\begin{array}{l}\text { Kelengkapan materi Koreksi/Registrasi Peta Hasil Scan dengan } \\
\text { kompetensi yang ingin dicapai }\end{array}$ & & & & \\
\hline 9 & $\begin{array}{l}\text { Kelengkapan materi Digitasi Elemen Titik, Garis, dan Luasan dengan } \\
\text { kompetensi yang ingin dicapai }\end{array}$ & & & & \\
\hline
\end{tabular}




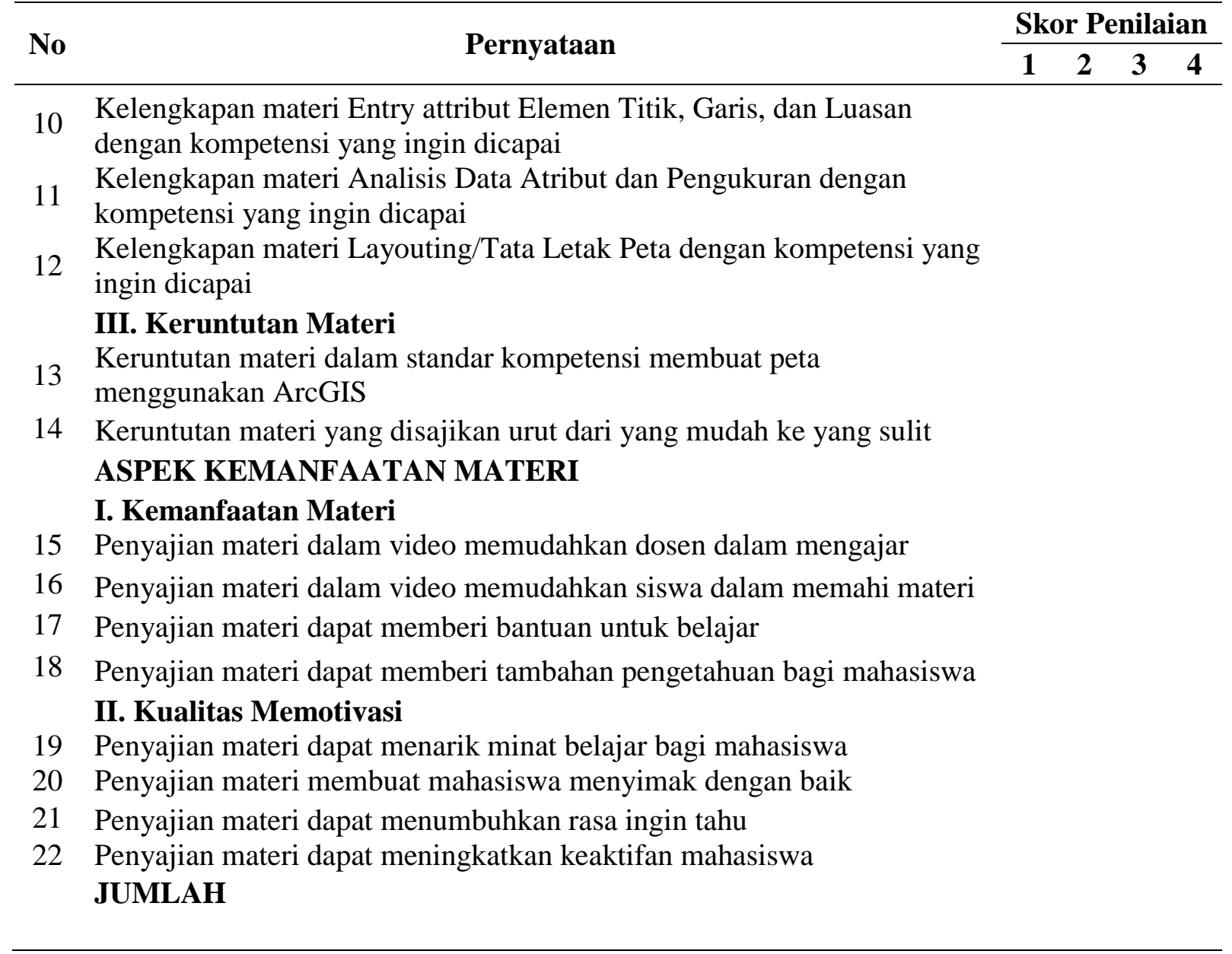

Tabel 2. Instrumen Validasi Media

\begin{tabular}{|c|c|c|c|c|c|}
\hline \multirow{2}{*}{ No } & \multirow{2}{*}{ Pernyataan } & \multicolumn{4}{|c|}{ Skor Penilaian } \\
\hline & & 1 & 2 & 3 & 4 \\
\hline & ASPEK KUALITAS MEDIA & & & & \\
\hline & I. Kualitas Video yang Ditampilkan & & & & \\
\hline & Kesesuaian gambar/video yang ditampilkan dengan materi yang & & & & \\
\hline 1 & disampaikan & & & & \\
\hline 2 & Kesesuaian ukuran gambar video yang digunakan dengan ukuran media & & & & \\
\hline 3 & Kejelasan gambar/video yang ditampilkan & & & & \\
\hline 4 & Kejelasan gambar/video dapat mendukung proses pembelajaran & & & & \\
\hline & II. Kemudahan Penggunaan & & & & \\
\hline 5 & $\begin{array}{l}\text { Kemudahan pengoperasian/penggunaan media pembelajaran video } \\
\text { tutorial }\end{array}$ & & & & \\
\hline 6 & $\begin{array}{l}\text { Kemudahan dalam memilih materi yang akan dipelajari } \\
\text { III. Kejelasan Suara }\end{array}$ & & & & \\
\hline 7 & Kejelasan penggunaan efek suara/music & & & & \\
\hline 8 & Kejelasan suara/musik membuat video menarik & & & & \\
\hline & IV. Kejelasan Teks/Keterbacaan & & & & \\
\hline 9 & Pemilihan warna teks dan background kontras sehingga mudah dibaca & & & & \\
\hline 10 & Kesesuaian ukuran huruf dengan background & & & & \\
\hline 11 & Kejelasan bentuk huruf & & & & \\
\hline
\end{tabular}




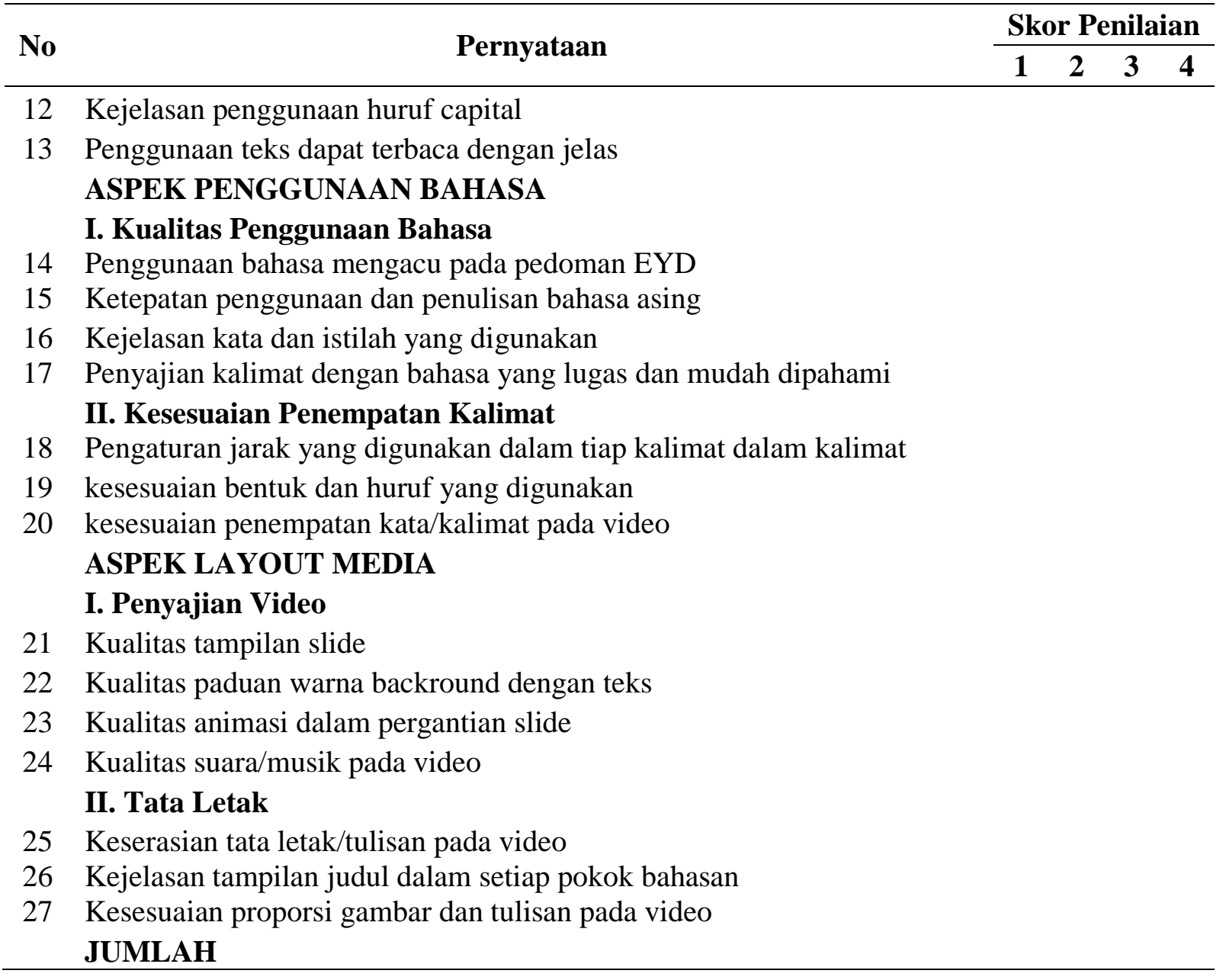

persentaseskor $=\frac{\Sigma \text { skorperolehan }}{\Sigma \text { skormaksimum }} \times 100 \%$

Tabel 3. Skala Persentase Validasi

\begin{tabular}{ccc}
\hline No & Persentase Pencapaian & Interpretasi \\
\hline 1 & $76-100 \%$ & sangat layak \\
2 & $56-75 \%$ & Layak \\
3 & $40-55 \%$ & Cukup \\
4 & $0-39 \%$ & kurang layak \\
\hline
\end{tabular}

Kedua, data mengenai respon mahasiwa dievaluasi dengan menggunakan angket. Tes ini dilakukan mahasiswa setelah mempelajari dan menggunakan multimedia
Tutorial pada Mata Kuliah Sistem Informasi Geografi (SIG). Angket respon mahasiswa terhadap video tutorial dapat dilihat pada Tabel 4.

Tabel 4. Angket Respon Mahasiswa Pengguna Video Tutorial SIG

\begin{tabular}{llll}
\hline \multirow{2}{*}{ No } & Pernyataan & \multicolumn{3}{c}{ Skor Penilaian } \\
\cline { 3 - 4 } & \multicolumn{1}{c}{$\mathbf{2}$} & $\mathbf{3}$ & $\mathbf{4}$ \\
\hline & & ASPEK TAMPILAN \\
1 & Penyajian video sesuai dengan materi yang diajarkan & & \\
2 & Kejelasan pada video/gambar dapat terlihat & \\
\hline
\end{tabular}




\begin{tabular}{|c|c|c|c|c|c|}
\hline \multirow{2}{*}{ No } & \multirow{2}{*}{ Pernyataan } & \multicolumn{4}{|c|}{ Skor Penilaian } \\
\hline & & 1 & 2 & 3 & 4 \\
\hline 3 & Penggunaan bahasa pada video mudah dimengerti & & & & \\
\hline 4 & Penggunaan bahasa pada video tegas dan jelas & & & & \\
\hline 5 & Penggunaan bahasa asing pada video dapat dimengerti & & & & \\
\hline 6 & Penggunaan jenis huruf dalam teks pada video ini tampak jelas & & & & \\
\hline 7 & Keterbacaan bentuk huruf yang digunakan & & & & \\
\hline 8 & $\begin{array}{l}\text { Pemilihan warna huruf kontras dengan background, sehingga teks dapat } \\
\text { terbaca }\end{array}$ & & & & \\
\hline & ASPEK PENGOPERASIAN & & & & \\
\hline 9 & Kemudahan media video tutorial ini untuk digunakan & & & & \\
\hline 10 & $\begin{array}{l}\text { Penyajian video tutorial ini sudah runtut dari materi yang mudah ke } \\
\text { materi yang sulit }\end{array}$ & & & & \\
\hline 11 & Kemudahan memilih tutorial yang akan dipelajari & & & & \\
\hline & ASPEK KEMANFAATAN & & & & \\
\hline 12 & $\begin{array}{l}\text { Penyajian video tutorial ini dapat mempermudah pembelajaran mandiri } \\
\text { mahasiswa }\end{array}$ & & & & \\
\hline 13 & $\begin{array}{l}\text { Penyajian video ini dapat menarik perhatian saya sehingga memberikan } \\
\text { rangsangan untuk belajar }\end{array}$ & & & & \\
\hline 14 & $\begin{array}{l}\text { Penyajian musik dapat menambha semangat saya untuk memperhatikan } \\
\text { pelajaran }\end{array}$ & & & & \\
\hline 15 & Penyajian video ini dapat membangkitkan daya tangkap belajar & & & & \\
\hline
\end{tabular}

Respon mahasiswa kemudian dihitung dengan menggunakan formula :

persentaseskor $=\frac{\Sigma \text { skorperolehan }}{\Sigma \text { skormaksimum }} \times 100 \%$

Tabel 5. Kategori Respon Mahasiswa Terhadap Video Tutorial

\begin{tabular}{cc}
\hline Rata - Rata Persentase Skor & Kategori \\
\hline$\leq 10$ & Sangat Buruk \\
$10-13$ & Buruk \\
$14-17$ & Cukup \\
$18-21$ & Baik \\
$\geq 22$ & Sangat Baik \\
\hline
\end{tabular}

\section{HASIL DAN PEMBAHASAN}

\section{Pengembangan Video Tutorial}

Video tutorial yang dikembangkan dalam penelitian ini menggunakan aplikasi Camtasia Studio 8.5 pada matakuliah Sistem Informasi Geografi (SIG) pada tahun ajaran 2017/2018. User interface (tampilan antar muka) aplikasi camtasia studio 8.5 dapat dilihat pada Gambar 1.

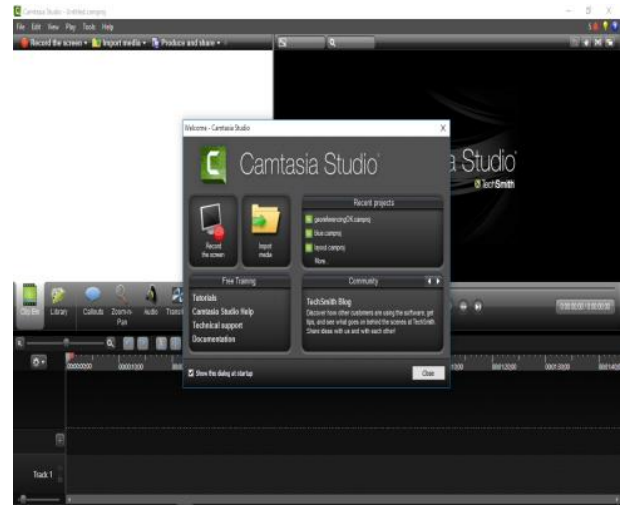

Gambar 1. User Interface Aplikasi

Camtasia Studio 8.5 
Video tutorial yang dikembangkan mengacu pada model Thiagarajan dan Semmel \& Semmel yang terdiri dari empat tahap yaitu: tahap define (penetapan), design (perancangan), develop (pengembangan), dan dessiminate (penyebaran). Tahap define dan design masuk pada fase perencanaan pengembangan sedangkan develop dan dessiminate masuk dalam fase pengembangan.

\section{Fase Perecanaan}

Fase perencanaan merupakan langkah awal dalam penyusunan video tutorial ini. Fase ini terdiri dari dua tahapan yaitu, tahap penetapan (define) dan tahap perancangan (desain).

\section{1) Tahap penetapan (define)}

Tahap Tahap define ini ialah tahap untuk menetapkan dan mendefinisikan syarat-syarat pembelajaran. Tahap ini mencakup langkah pokok berikut yaitu:

Pertama, analisis ujung depan. Analisis ujung depan bertujuan untuk memunculkan dan menetapkan masalah besar yang dihadapi dalam pembelajaran (Thiagarajan dkk, 1974). Permasalahan utama dalam pembelajaran SIG ialah tidak cukupnya waktu pembelajaran untuk menjelaskan secara langsung (ekspository) langkah pembuatan peta dengan menggunakan aplikasi Arc GiS 10.2, sedangkan capaian pembelajaran pada silabus matakuliah SIG sangat banyak. Selain itu, permasalahan lain ialah pengajaran langsung sangat tidak efektif dalam meningkatkan pemahaman mahasiswa mengenai Sistem informasi geografi. Ketersediaan media pembelajaran pada matakuliah SIG selama ini belum mencukupi untuk mengatasi permasalahan tersebut, sehingga dibutuhkan suatu media inovatif yang secara efektif mampu meningkatkan pemahaman dan keterampilan mahasiswa dalam membuat peta, tetapi tidak memakan waktu yang panjang dalam perkuliahan tatap muka. Oleh karena itu, peneliti berinisiatif untuk mengembangkan suatu media pembelajaran dalam bentuk video tutorial dengan menggunakan Aplikasi Camtasia Studio 8.5.
Kedua, tahapan analisis mahasiswa. Menurut Thiagarajan, dkk (1974) analisis siswa merupakan telaah tentang karakteristik siswa yang sesuai dengan desain pengembangan perangkat pembelajaran. Karakteristik mahasiswa yang ingin dibentuk dalam proses pembelajaran ialah terampil dalam mengaplikasikan Arc Gis 10.2 untuk membuat peta. Namun berdasarkan pengalaman pada tahun sebelumnya, sangat sedikit mahasiswa geografi yang terampil mengaplikasikan Arc Gis 10.2 untuk membuat peta guna berbagai keperluan. Hal ini merupakan permasalahan yang urgent diatasi mengingat ciri khas dari Jurusan Pendidikan Geografi dibandingkan jurusan lain salah satunya terletak pada keterampilan ini.

Ketiga, penyusunan perangkat pembelajaran. Perangkat pembelajaran merupakan salah satu prasyarat penting yang harus dipenuhi oleh seorang dosen sebelum proses pembelajaran berlangsung. Dalam perangkat pembelajaran semua tujuan, isi, dan langkah pembelajaran dituangkan secara runtut dan jelas serta harus mengacu kepada Standar Nasional Pendidikan Tinggi untuk setiap Program Studi yang mencakup pengembangan kecerdasan intelektual, akhlak mulia, dan keterampilan.Standar kurikulum yang disusun oleh institusi pendidikan tinggi dan diteruskan dalam bentuk yang lebih rinci pada perangkat pembelajaran didasarkan pada fakta bahwa target Capaian Pembelajaran/CP (Learning Outcome/LO) dapat dipenuhi melalui isi dan proses pembelajaran. Capaian Pembelajaran (CP) yang dicanangkan dalam lingkup pendidikan nasional mengacu pada perkembangan ilmu pengetahuan, teknologi dan budaya global yang tidak terlepas dari perkembangan kapasitas dan potensi sumber daya manusianya.

Perencanaan proses pembelajaran Sistem Informasi Geografi (SIG) yang telah disusun disajikan dalam bentuk Rencana Pembelajaran Semester (RPS) dan Kontrak Perkuliahan. Rencana pembelajaran semester (RPS) ditetapkan dan dikembangkan mandiri sesuai dengan keahlian suatu bidang ilmu pengetahuan dan/atau teknologi dalam program studi. 
Komponen Rencana pembelajaran semester (RPS) disesuaikan dengan buku I KKNI mengenai pedoman akademik Jurusan Pendidikan Geografi. Komponen minimal yang harus ada dalam suatu rencana pembelajaran ialah:

a. Nama program studi, nama dan kode mata kuliah, semester, sks, nama dosen pengampu

b. Capaian pembelajaran lulusan yang dibebankan pada mata kuliah

c. Kemampuan akhir yang direncanakan pada tiap tahap pembelajaran untuk memenuhi capaian pembelajaran lulusan

d. Bahan kajian yang terkait dengan kemampuan yang akan dicapai

e. Metode pembelajaran

f. Waktu yang disediakan untuk mencapai kemampuan pada tiap tahap pembelajaran

g. Pengalaman belajar mahasiswa yang diwujudkan dalam deskripsi tugas yang harus dikerjakan oleh mahasiswa selama satu semester

h. Kriteria, indikator, dan bobot penilaian

i. Daftar referensi yang digunakan.

\section{2) Tahap perancangan (desain)}

Tahap perancangan atau penyusunan video tutorial SIG ialah merancang atau mendesain video sesuai dengan capaian pembelajaran yang terdapat pada Rencana Pembelajaran Semester (RPS) yang sudah dirancang sebelumnya. Tujuan pembelajaran yang terdapat dalam RPS antara lain: (1) Mempersiapkan data masukan untuk mempersiapkan peta digital berbasis SIG serta melakukan koreksi geometri, (2) Digitasi peta dan editing peta dengan menggunakan software SIG, (3) mengelola atribut pada peta digital, (4) melakukan geoprocessing data vektor menggunakan tools pada perangkat lunak SIG, dan (5) melakukan penyajian dan layout peta geografi. Recording dan editing seluruh aktivitas ini pada layar monitor dilakukan dengan menggunakan aplikasi camtasia studio. Proses editing ini meliputi penambahan teks, suara, animasi, musik, dan tombol sehingga video tutorial menjadi lebih menarik. Metode pembelajaran yang diterapkan adalah metode praktikum dengan menggunakan media pembelajaran berbantuan komputer dan Liquid Crystal Display (LCD) viewer projector untuk penyampaian materi. Berikut adalah desain rancangan tampilan awal media pembelajaran video tutorial.

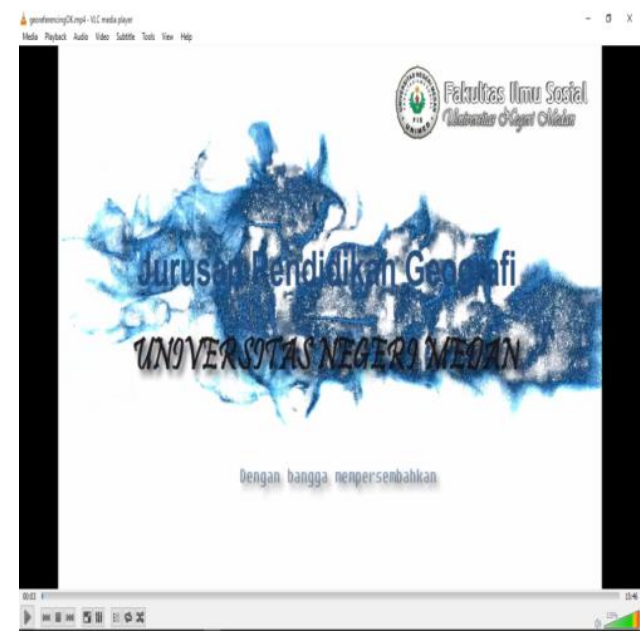

\section{Gambar 2. Tampilan Awal Media Pembelajaran Video Tutorial}

Selain itu, dalam mendesain video tutorial, penulis menggunakan kriteria kualitas dan kemanfaatan materi,kualitas dan layout media serta penggunaan bahasa.

\section{Fase Pengembangan}

Video tutorial yang telah disusun sebelumnya perlu dievaluasi lebih lanjut oleh para ahli sebelum digunakan secara umum di lingkungan akademis. Hal ini dimaksudkan agar video tutorial yang akan digunakan tersebut benar-benar sudah layak untuk dimanfaatkan terutama oleh mahasiswa Jurusan Pendidikan Geografi FIS Universitas Negeri Medan.

\section{Validasi dan Uji Coba Produk}

Hasil pengembangan media pembelajaran video tutorial pengoperasian software ArcGIS diperoleh data-data, yaitu (1) Data evaluasi ahli materi yang terdiri dari data hasil validasi, hasil analisis dan masukan atau revisi. (2) Data evaluasi ahli media yang terdiri dari data hasil validasi, hasil analisis dan masukan atau revisi.

Validasi yang dilakukan oleh ahli materi terhadap media pembelajaran 
melingkupi aspek kualitas materi dan kemanfaatan materi. Validasi terhadap aspek kualitas materi meliputi beberapa hal antara lain: ketepatan materi dengan kompetensi yang akan dicapai, kelengkapan materi, keruntutan materi. Validasi terhadap aspek kemanfaatan materi meliputi: kemanfaatan materi dan kualitas memotivasi.

Validasi ahli media terhadap media pembelajaran meliputi aspek kualitas media, aspek penggunaan bahasa, dan layout media. Validasi terhadap aspek kualitas media meliputi: kualitas video yang ditampilkan, kemudahan penggunaan, kejelasan suara, dan kejelasan teks/keterbacaan. Validasi terhadap aspek penggunaan bahasa meliputi: kualitas penggunaan bahasa dan kesesuaian penempatan kalimat. Validasi terhadap aspek layout media meliputi: penyajian video dan tata letak.

Hasil validasi ahli materi dan ahli media dijadikan dasar untuk merevisi media dari isi materi sampai tampilan. Hasil validasi para ahli dijadikan tolok ukur tentang layak tidaknya media pembelajaran untuk diujicobakan di lapangan.

\section{a) Tinjauan Ahli Materi 1}

Angket penilaian oleh ahli materi meliputi dua aspek yaitu aspek kualitas materi dan aspek kemanfaatan materi. Data hasil validasi oleh ahli materi 1 dapat dilihat pada Tabel 6.

Tabel 6. Skor Validasi I Ahli Materi

\begin{tabular}{|c|c|c|c|c|c|c|c|c|c|}
\hline \multirow{2}{*}{ No } & \multirow{2}{*}{ Aspek } & \multicolumn{4}{|c|}{ Frekuensi } & \multirow{2}{*}{$\begin{array}{l}\text { Total } \\
\text { Skor }\end{array}$} & \multirow{2}{*}{$\begin{array}{c}\text { Jumlah } \\
\text { Butir }\end{array}$} & \multirow{2}{*}{$\begin{array}{l}\text { Bobot } \\
\max \end{array}$} & \multirow{2}{*}{$\%$} \\
\hline & & 1 & 2 & 3 & 4 & & & & \\
\hline 1 & Kualitas Materi & 0 & 8 & 6 & 0 & 34 & 14 & 56 & 60.71 \\
\hline 2 & Kemanfaatan Materi & 2 & 4 & 2 & 0 & 16 & 8 & 32 & 50 \\
\hline & Jumlah & & & & & 50 & 22 & 88 & 56.82 \\
\hline
\end{tabular}

Hasil yang terdapat pada Tabel 6 kemudian ditangkan dalam bentuk diagaram seperti Gambar 3.

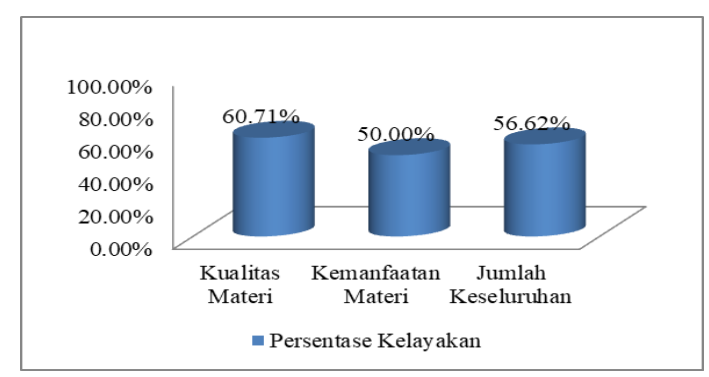

Gambar 3. Diagram Persentase Hasil Validasi I Ahli Materi

Hasil penilaian pada tahap Validasi I oleh ahli materi ini ditinjau dari aspek (1) kualitas materi, memperoleh skor 34 $(60.71 \%)$ dan (2) kemanfaatan materi memperoleh skor 16 (50\%). Secara keseluruhan tingkat validasi materi pembelajaran video tutorial memperoleh skor $50(56.82 \%)$. Skor 50 yang diperoleh dari ahli materi 1 dengan persentase $56.82 \%$ menunjukan media pembelajaran ini dilihat dari materinya dikategorikan layak digunakan dengan revisi. Beberapa revisi yang disarankan oleh ahli materi 1 ialah teknik mendigitasi divisualisasikan lebih terperinci, langkah melakukan georeferencing peta gunakanlah metode yang simple dan mudah dimengerti, dan materi editing ditambah agar lebih jelas.

\section{b) Tinjauan ahli materi 2}

Hasil penilaian dari ahli media 2 ini ditinjau dari aspek kualitas materi dan aspek kemanfaatan materi. Data validasi dari ahli materi 2 dapat dilihat pada Tabel 7.

Tabel 7. Skor Penilaian Ahli Materi 2

\begin{tabular}{|c|c|c|c|c|c|c|c|c|c|}
\hline \multirow[b]{2}{*}{ No } & \multirow[b]{2}{*}{ Aspek } & \multicolumn{4}{|c|}{ Frekuensi } & \multirow{2}{*}{$\begin{array}{c}\text { Jumlah } \\
\text { Skor }\end{array}$} & \multirow{2}{*}{$\begin{array}{c}\text { Jumlah } \\
\text { Butir }\end{array}$} & \multirow{2}{*}{$\begin{array}{c}\text { Bobot } \\
\text { max }\end{array}$} & \multirow[b]{2}{*}{$\%$} \\
\hline & & 1 & 2 & 3 & 4 & & & & \\
\hline 1 & Kualitas Materi & 0 & 0 & 7 & 7 & 49 & 14 & 56 & 87.50 \\
\hline 2 & Kemanfaatan Materi & 0 & 0 & 4 & 4 & 28 & 8 & 32 & 87.50 \\
\hline & Jumlah & & & & & 77 & 22 & 88 & 87.50 \\
\hline
\end{tabular}


Hasil yang terdapat pada Tabel 7 kemudian ditangkan dalam bentuk diagaram seperti Gambar 4 dibawah ini

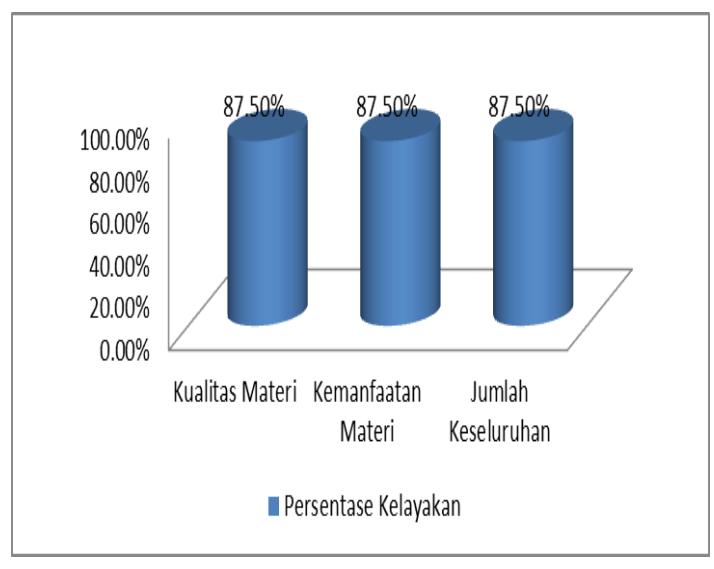

Gambar 4. Diagram persentase hasil penilaian ahli materi 2
Tabel 6, dan 7 dan Gambar 3 dan 4 menunjukkan bahwa perolehan skor pada aspek kualitas materi sebesar 49 atau $87.50 \%$ dan kemanfaatan materi sebesar 28 atau $87.50 \%$. secara keseluruhan tingkat validasi materi pembelajaran video tutorial memperoleh $87.50 \quad \% \quad$ sehingga dikategorikan sangat layak untuk digunakan dengan revisi. Revisi produk yang disarankan oleh ahli materi pada tahap kedua ini ialah agar peneliti menambahkan video untuk materi tingkat lanjut.

\section{c) Tinjauan Ahli Media tahap 1}

Validasi oleh ahli media tahap 1 meliputi tiga aspek yaitu aspek kualitas media, aspek penggunaan bahasa, aspek layout media. Data hasil validasi ahli media 1 dapat dilihat pada tabel 8 berikut.

Tabel 8. Skor Perolehan Ahli Media Tahap 1

\begin{tabular}{clrlllccccc}
\hline & & \multicolumn{4}{c}{ Frekuensi } & Jumlah & Jumlah & Bobot \\
\cline { 2 - 6 } No & Aspek & 1 & 2 & 3 & 4 & Skor & Butir & max & $\%$ \\
1 & Kualitas Media & 5 & 5 & 3 & 0 & 24 & 13 & 52 & 46.15 \\
2 & Penggunaan Bahasa & 0 & 4 & 3 & 0 & 17 & 7 & 28 & 60.71 \\
3 & Layout Media & 3 & 3 & 1 & 0 & 16 & 7 & 28 & 57.14 \\
& & Jumlah & & & & 57 & 27 & 108 & 52.78 \\
\hline
\end{tabular}

Sumber: Hasil Penelitian, 2017

Hasil yang terdapat pada Tabel 8 kemudian ditangkan dalam bentuk diagaram seperti Gambar 5 dibawah ini

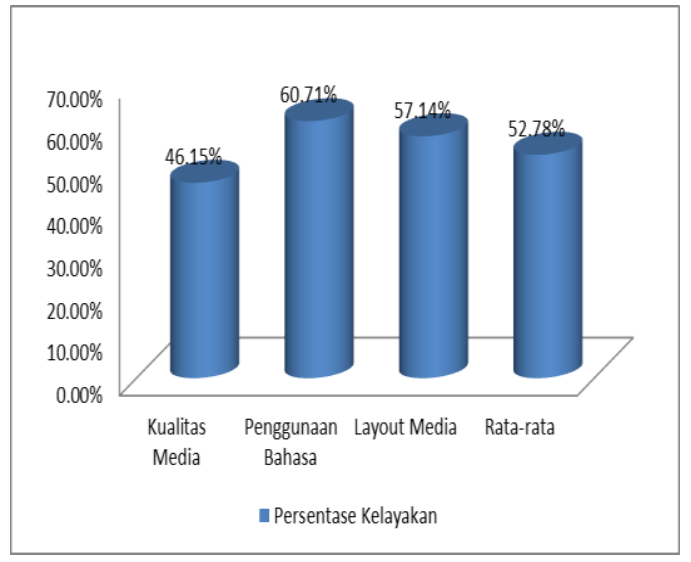

Gambar 5. diagram persentase hasil penilaian ahli media tahap 1
Hasil penilaian ahli media pada tahap 1 menunjukan bahwa: (1) aspek kualitas media memperoleh skor 24 atau sebesar 46,15\%, (2) penggunaan bahasa dengan skor 17 atau $60,71 \%$, (3) layout media dengan skor 16 atau 57,14\%. Persentase rata - rata dari ketiga aspek media sebesar $52,78 \%$ terkategori cukup layak digunakan dengan revisi. Revisi yang harus dilaksanakan berdasarkan saran dari ahli media ialah penambahan teks atau tulisan pada video, penambahan musik pada video, detail petunjuk tombol diperjelas, gunakan cut frame lebih banyak agar durasi video lebih singkat, dan gunakan zoom in maupun zoom out agar setiap langkah tergambar jelas di video. 


\section{d) Tinjauan Ahli Media Tahap 2}

Setelah dilakukan revisi pada video tutorial berdasarkan saran dari ahli media sebelumnya, maka dilakukan validasi kedua. Hasil penilaian ahli media pada tahap 2 ini menunjukan bahwa pada aspek: (1) kualitas media, ahli media menilai sebesar 44 atau $84,62 \%$, (2) penggunaan bahasa sebesar 23 atau $82,14 \%$, (3) layout media ebesar 24 atau $85,71 \%$. Dari ketiga aspek tersebut diperoleh rata-rata persentase sebesar $84,26 \%$. Dengan nilai rata-rata ini media pembelajaran dikategorikan sangat layak untuk digunakan dari kualitas media. Skor Perolehan Ahli Media dapat dilihat pada Tabel 9.

Tabel 9. Skor Perolehan Ahli Media Tahap 2

\begin{tabular}{|c|c|c|c|c|c|c|c|c|c|}
\hline \multirow{2}{*}{ No } & \multirow{2}{*}{ Aspek } & \multicolumn{4}{|c|}{ Frekuensi } & \multirow{2}{*}{$\begin{array}{l}\text { Jumla } \\
\text { h skor }\end{array}$} & \multirow{2}{*}{$\begin{array}{l}\text { Jumla } \\
\text { h butir }\end{array}$} & \multirow{2}{*}{$\begin{array}{c}\text { Bobot } \\
\max \end{array}$} & \multirow{2}{*}{$\%$} \\
\hline & & 1 & 2 & 3 & 4 & & & & \\
\hline 1 & Kualitas Media & 0 & 0 & 8 & 5 & 44 & 13 & 52 & 84.62 \\
\hline 2 & Penggunaan Bahasa & 0 & 0 & 5 & 2 & 23 & 7 & 28 & 82.14 \\
\hline 3 & Layout Media & 0 & 0 & 4 & 3 & 24 & 7 & 28 & 85.71 \\
\hline \multicolumn{6}{|c|}{ Jumlah } & 91 & 27 & 108 & 84.26 \\
\hline
\end{tabular}

Hasil yang terdapat pada Tabel 9 kemudian ditangkan dalam bentuk diagaram seperti Gambar 6.

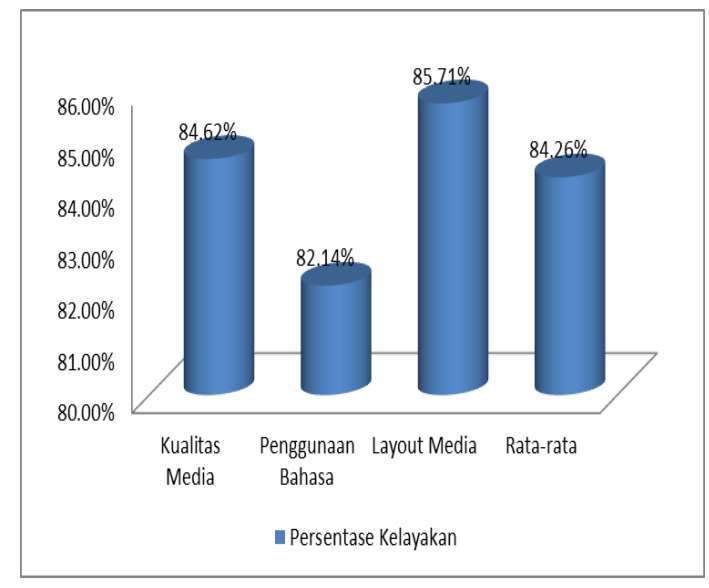

Gambar 6. Skor Perolehan Ahli Media Tahap 2

Fase uji coba pengembangan

Tahap selanjutnya setelah uji validasi oleh pakar ialah tahap uji coba pengembangan media pembelajaran ke kelas eksperimen, yaitu kelas A regular TA 2017/2018. Tahap uji coba pengembangan ini dimaksudkan untuk mengetahui respon mahasiswa pengguna media pembelajaran dalam bentuk video tutorial. Melalui tahap uji coba ini diharapkan dapat diperoleh kritikan dan saran berkenaan untuk perbaikan media pembelejaran selanjutnya.

\section{Respon Mahasiswa}

Respon mahasiswa merupakan faktor penting dalam menganalisis kelayakan video tutorial pada matakuliah Sistem Informasi Geografi (SIG). Respon mahasiswa ini dinilai dengan menggunakan lembar angket (quisioner) oleh 25 orang mahasiswa yang telah menggunakan video tutorial SIG yaitu kelas A Reguler angkatan 2015.

Skor data tanggapan mahasiswa terhadap media video tutorial disusun dalam tabulasi data. Data selengkapnya dapat dilihat pada Lampiran. Kemudian dikualifikasikan dengan mencari persentase seluruh aspek. Setelah memperoleh persentase tertinggi dan terendah, langkah selanjutnya adalah menentukan interval kelas. Maka criteria yang diterapkan untuk kuesioner adalah Tidak Baik $=25 \%-44 \%$; Kurang Baik $=45 \%-63 \%$; Baik $=64 \%-$ 83\%; Baik Sekali $=84 \%-100 \%$.

Tanggapan mahasiswa tentang pengembangan dan penerapan media pembelajaran berbasis media video tutorial diperoleh melalui lembar angket. Pengambilan data ini dilakukan pada akhir pembelajaran. Data selengkapnya dapat dilihat pada Lampiran. Hasil respon mahasiswa yang mengambil matakuliah Sistem Informasi Geografi (SIG) dapat dilihat pada Tabel 10 dan Gambar 7. 
Tabel 10. Hasil Respon Mahasiswa Terhadap Media Video Tutorial

\begin{tabular}{rlrrrrc}
\hline No & Aspek yang Dinilai & Jumlah Butir & Skor Maks & Skor Perolehan & Persentase (\%) & Respon \\
\hline 1 & Tampilan & 8 & 32 & 24.52 & 76.62 & Baik \\
2 & Pengoperasian & 3 & 12 & 10.76 & 89.67 & Baik Sekali \\
3 & Kemanfaatan & 4 & 16 & 12.16 & 76 & Baik \\
& & 15 & 60 & 47.44 & $\mathbf{8 0 . 7 6}$ & Baik \\
\hline
\end{tabular}

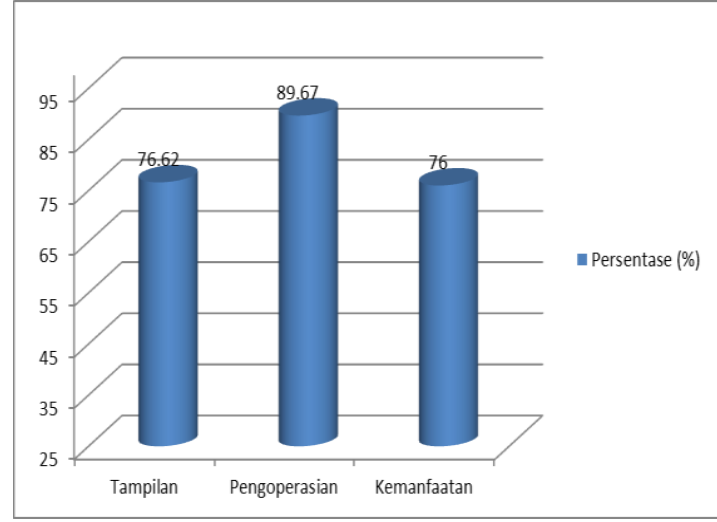

Gambar 7. Diagram Hasil Respon Mahasiswa Terhadap Media Video Tutorial

Berdasarkan Tabel 10 dan Gambar 8 menunjukkan bahwa skor perolehan hasil respon mahasiswa terhadap penggunaan media video tutorial dalam aspek tampilan sebesar 24,52 dengan persentase sebesar $76,62 \%$ masuk dalam kategori Baik. Sedangkan dari aspek pengoperasian diperoleh skor 10,76 dengan persentase sebesar 89,67\% masuk dalam kategori Baik Sekali. Dalam aspek Kemanfaatan video tutorial perolehan skos sebesar 12,6 dengan persentase sebesar 76\% masuk dalam kategori Baik. Dari ketiga aspek respon mahasiswa tersebut kemudian dirata-ratakan sehingga didapat kesimpulan bahwa skor perolehan total sebesar 47,44 dengan persentase sebesar $80,76 \%$ masuk dalam kategori Baik. Hal ini menunjukkan bahwa pengembangan video tutorial menggunakan Camtasia Studio 8.5 pada matakuliah Sistem Informasi Geografi (SIG) sudah bagus dan mendapatkan respon yang positif dari mahasiswa.

\section{SIMPULAN DAN SARAN}

Hasil uji kelayakan dari segi materi pada pengembangan video tutorial menggunakan Camtasia Studio 8.5 pada matakuliah Sistem Informasi Geografi (SIG) dikategorikan sangat layak untuk digunakan dengan catatan perlu dilakukan revisi. Sedangkan hasil uji kelayakan dari segi media dikategorikan cukup layak digunakan dengan beberapa revisi, diantaranya: penambahan teks dan tulisan, musik, detail petunjuk tombol, dan lain sebagainya.

Hasil respon mahasiswa mengenai pengembangan video tutorial menggunakan Camtasia Studio 8.5 pada matakuliah Sistem Informasi Geografi (SIG) masuk dalam kategori baik. Hal ini menunjukkan bahwa pengembangan video sudah bagus dan mendapatkan respon positif dari mahasiswa.

Perlu adanya pengembangan lebih lanjut mengenai video tutorial pada pembelajaran menggunakan aplikasi Camtasia Studio 8.5 mengingat banyak sekali menu dan fasilitas yang bias dimanfaatkan lebih lanjut guna menghasilkan video tutorial yang efektif meningkatkan pemahaman mahasiswa dalam pembelajaran.

Demi kepraktisan dan keefektifan video tutorial, integrasi video menggunakan Camtasia Studio perlu diintegrasikan dengan media pembelajaran berbasis multimedia yang lain misalnya Macromedia Flash sehingga nantinya video tutorial bisa diintegrasikan dengan tujuan pembelajaran, materi, latihan, serta evaluasi.

\section{DAFTAR RUJUKAN}

Arifin, B. (2009). Step By Step Membuat Video Tutorial Menggunakan Camtasia Studio. Bandung: Oase Media.

Arsyad, A. (2007). Media Pembelajaran. Jakarta: PT Raja Grafindo Persada.

Aulia, N. W., \& Aina, M. (2016). Pengembangan Multimedia Interaktif Menggunakan Camtasia Studio 8 Pada Pembelajaran Biologi 
Materi Kultur Jaringan untuk Siswa SMA Kelas XI MIA. Biodik, 2(1), 20-26.

Kustiono, K. (2010). Media Pembelajaran: Konsep, Nilai Edukatif, Klasifiasi, Praktek Pemanfaatan dan Pengembangan. Semarang: Unnes Press.

Pritandhari, M., \& Ratnawuri, T. (2015). Evaluasi Penggunaan Video Tutorial Sebagai Media Pembelajaran Semester IV Program Studi Pendidikan Ekonomi Universitas Muhammadiyah Metro. JURNAL PROMOSI: Jurnal Pendidikan Ekonomi UM Metro, 11-20.

Riyana, C. (2007). Pedoman Pengembangan Media Video. Jakarta: P3AI UPI.

Setiawan, C. (2011). Pembuatan Video Materi Ajar dengan Camtasia. Universitas Brawijaya: Pelatihan Pengembangan Materi Ajar Pusbangtendik.

Sudjana, N., \& Rivai, A. (1990). Media Pengajaran: Penggunaan dan Pembuatannya. CV Sinar Baru, Bandung.

Tyas, N. K. (2015). Penggunaan Video Tutorial untuk Meningkatkan Kemampuan Berbicara Bahasa Inggris Mahasiswa Sekolah Tinggi Elektronika dan Komputer (STEKOM) Semarang. PIXEL: Jurnal Ilmiah Komputer Grafis. Vol. 8 No 1 (hal 53-56). 